\title{
The Physical Discourse of Fan Fiction
}

\section{Дискурс тілесності в текстах Fan Fiction}

\section{Zoriana Hodunok}

Ph.D. in Philology,

Senior Lecturer

\section{Зоряна Годунок}

кандидат філологічних наук, старший викладач

E-mail: zrya89@gmail.com orcid.org/0000-0001-8300-432X

Researcher ID: 0-3288-2018

National University of Ostroh Academy 2, Seminarska Str., Ostroh, Rivne reg., Ukraine, 35800
Національний університет «Острозька академія»

$\triangle$ вул. Семінарська, 2, м. Острог, Рівненська обл., Україна, 35800

Original manuscript received February 23, 2018

Revised manuscript accepted October 07, 2018

\section{ABSTRACT}

The research of physical discourse, typical characters, stereotypical gender roles of fan fiction's texts, based on "Harry Potter», "Supernatural», "The Song of Ice and Fire»/"The Game of Throne», is realized in the article. The author uses Psycholinguistics (Frame Method and Free Associative Experiment), Hermeneutics, some elements of Comparative analysis to describe the main characteristics of the personages and explain peculiarities of their sexual interactions.

Fan fiction prose is a kind of virtual mass literature, so it has special features inherent to mass literature in general, for example, comfort reading, typical personages in typical dramatic plot, often - happy end etc.

The physical discourse is the most important part of fan fiction's texts, because the experience of sexual interactions is desirable for a person and it is a base of human's life. The frame "body" covers not only sex, but also love and security (for example, to be safe in one's hands). The most frequent nouns of the frame are "hands/fingers" and "eyes/gaze». It is important to note 
that man's hands and eyes often show his character. But woman's eyes and hands realize her emotions and feelings. It depends on stereotypical gender roles of mass culture: man has a function to interact with the world, and woman has a function to safe life inside (to give birth), which is confirmed by the free associative experiment.

Physical damages (scars, injuries, deceases - for man; rapes - for woman) make the personages more emotionally close to a reader of fan fiction; show an act of initiation (transition from the fandom text to fan fiction text).

Key words: fan fiction, original text, fandom character, fan fiction character, physical discourse, physical and psychological damages.

\section{Вступ}

Fan fiction - це група текстів віртуальної літератури авторства реципієнтів, захоплених певним фандомом, оригінальним текстом художньої літератури, фільму, серіалу тощо, грунтованих на сюжеті, за участю персонажів оригінальних текстів, але з певними відмінностями:

- тексти fan fiction часто змінюють сюжет, або принаймні одну 3 сюжетних ліній, чи розв'язку оригінального тексту, продовжуючи сюжет там, де він завершується у тексті фандомі;

- змінюють характери персонажів (Out of Character);

- зводять персонажів, які не були разом у тексті-оригіналі, і розвивають саме таку - любовну - лінію, наприклад, Северус Снейп i Герміона Грейнджер, Луна Лавгуд i Драко Малфой тощо («поттеріана» Дж.К. Ролінг); Санса Старк і Сандор Кліган, Санса Старк і Тиріон Ланістер тощо («Пісня льоду й полум'я» Дж. Мартіна/ «Гра престолів»); Сем і Дін Вінчестери, персонажі брати 3 серіалу «Надприродне», або Джаред Падалекі й Дженсен Екклз, актори, які грають ці ролі, та ін.;

- змінюють хронотоп (так, у контексті розгортання fan fiction фандому «Надприродного» автори фанфіків навіть створюють омегаверсум - окрему реальність, де істоти 3 фізіологічним/ біологічними характеристиками чоловіків можуть бути або альфами, самцями, або омегами, тими, хто фізично слабший, хто може виносити дитину альфи, самицями).

Подібні тексти виразно акцентують свою належність до дискурсу масової культури; найперше, така належність грунтується 
на спрощеному, комфортному читанні, реалізованому завдяки використанню типових сюжетів, зазвичай романтичних/любовних чи/i пригодницьких, стереотипів масової свідомості, зокрема й гендерних, тяжінню до драматизму, happy end та ін.

Fan fiction - це цікавий психологічний феномен, який актуалізує симптоматичні для рецептивної естетики й герменевтики питання сприйняття твору мистецтва реципієнтом, співтворчості реципієнта, зокрема як коментування одного мистецького твору іншим, тощо (див. праці Г.Г. Гадамера (Гадамер, 2001), Г.Р. Яуса (Яус, 2011) та ін.). Можемо розглядати явище fan fiction також i в ключі тематичного мислення (див., наприклад: (Estes, Golonka \& Jones, 2011)).

Дослідження fan fiction реалізуються здебільшого в зарубіжному науковому дискурсі, причому йдеться тут як про теоретико-медодологічні студії fan fiction (проблеми жанровизначення й рецепціï (Post-tolkienesque fanfiction: cultural parasites or literary commentaries by Grzegorz Trębicki; "I really have no idea what non-fandom people do with their lives». A multimodal and corpus-based analysis of fanfiction by M.G. Sindoni), авторської самоідентифікації ( II really have no idea what non-fandom people do with their lives». A multimodal and corpus-based analysis of fanfiction by M.G. Sindoni) гендерної ідентичності (Questions of Sexual Identity and Female Empowerment in Fan Fiction by C. Antoniolli (Antoniolli, 2016-2017)), так і про історико-літературні студії щодо окремих фандомів (наприклад, Supernatural Fangirls by K. Larsen and L.S. Zubernis; Post-tolkienesque fanfiction: cultural parasites or literary commentaries by Grzegorz Trębicki та ін.) /названі тексти можна знайти за таким покликанням: https://www.academia.edu/Documents/ in/Fanfiction_Studies/. Але попри достатню популярність цього виду творчості в мережі Інтернет, в українському науковому дискурсі важко знайти праці такої проблематики. Тож наша стаття є однією 3 перших наукових розвідок відповідної тематики в українському літературознавстві.

Метою статmі $є$ представлення результатів вивчення основних характеристик дискурсу тілесності fan fiction, зокрема й тих текстів, які стосуються проблеми фізичної / психологічної травми персонажів, що означує проблему психоемоційного наближення персонажів фандомів до автора/реципієнта фанфіків. 
Завдання: 1) пояснити особливості реалізації дискурсу тілесності в текстах fan fiction; 2) окреслити основні причини надання персонажам fan fiction певних фізичних/психічних/психологічних ушкоджень; 3) акцентувати гендерні аспекти втілення дискурсу тілесності, зокрема й ушкодженої тілесності.

\section{Методи й методики дослідження}

Для досягнення мети у статті використано психоаналітичний (зокрема фреймовий аналіз та вільний асоціативний експеримент), герменевтичний, компаративний та елементи семіотикоструктурального підходів до тлумачення текстів fan fiction.

Вільний асоціативний експеримент (далі - BAE - 3. Г.) було проведено засобами соціальної мережі Facebook у період iз 21 червня по 4 липня 2018 року. Він дав можливість виявити асоціативне смислове поле важливих для реалізації дискурсу тілесності концептів (руки; очі; у зв'язку з тим, що тексти fan fiction грунтовані здебільшого на гендерних стереотипах, ми використовували концепти «жіночі руки» / «чоловічі руки»; «жіночі очі» / «чоловічі очі»). Теоретико-методологічне підгрунтя ВАE задали праці С. Засєкіна (Засєкін, 2012), Ч. Осгуда (Osgood, Subeok, 1954), Б.А. Обера, І.К. Шенота (Ober, Shenaut, 2006), Дейна, Стормса (Deyne, Storms, 2008) та, частково, О. Балабан (Балабан, 2017), які актуалізують питання взаємозв'язків мови / мовлення / мислення; тлумачать поняття асоціативного значеннєвого i/чи смислового поля /концепту/; надають теоретичне і практичне пояснення психолінгвістичної зумовленості картини світу тощо.

У ВАЕ взяло участь 278 респондентів, які потенційно можуть бути читачами текстів fan fiction, із них: за віковим критерієм це молодь віком від 18 до 34 років; за гендерним критерієм: 178 жінок та 100 чоловіків (читачами текстів fan fiction $є$ здебільшого жінки, тож такий розподіл респондентів видається цілком виправданим); за географічним критерієм - це жителі України (близько 90\% респондентів), а також Білорусі, Індії, США (близько 10\%); за мовним критерієм - україномовні (близько 80\%), російськомовні (близько 15\%), англомовні (близько 5\%) респонденти.

Усього було опрацьовано 3043 реакції. Варто зазначити: результати дослідження вказують, що значна частина реакцій актуалізує саме смислові зв'язки (Vivas, Manoiloff, García, Lizarralde, 
Vivas, 2018), що зумовлено осмисленням аналізованих явищ саме в контексті /масової/ культури.

\section{Результати та дискусії}

Дискурс тілесного в масовій літературі, а саме до такої належать тексти fan fiction, $є$ одним із визначальних. Цьому можна виділити кілька вагомих причин: по-перше, в ньому кодується власне тілесною ще й духовна/душевна близькість 3 Іншим, що $€$ бажаним досвідом для автора/реципієнта (як указує К. Антоніоллі, «... fan fiction $\epsilon$ рефлексією найглибших бажань...» (Antoniolli, 20162017) (переклад наш - 3. В.)); по-друге, секс (і любов) є однією 3 базових потреб індивіда (див., піраміду А. Маслоу). Власне, через фізіологію у фанфіках цілком реалізується потреба людини в безпеці («... when Jared tugs his fingers free, Jensen hugs him tight to his chest, where it's safe, where Jared will always be safe...»/ LLike a detuned radio», Archive of Our Own/ (homo_pink, 2013)) і в любові («... Северус целует меня днем в лаборатории - в лоб, спокойно и нетребовательно. Я прислоняюсь к его плечу, прикрыв глаза и наслаждаясь теплом [...] глупо улыбаясь ему в шею...»/«Pабота над ошибками», Книга фанфиков/ (Contesina, 2013)).

Дискурс тілесності fan fiction включає в себе кілька важливих аспектів: саме тіло стає індикатором близькості чи іiі бажання між індивідами (як фізичної, так і духовної/душевної): «Я не желаю сегодня смотреть на его трясущиеся руки и сходить с ума вместе с ним» або «У него на правом плече безобразный шрам [...] Раньше я избегела смотреть на этот рубец. Сейчас я припасаюсь к нему губами [...] Я просто хочу дать знать, что он не один. И что я тоже не останусь одна» (виділення наше - 3. Г.) /«Работа над ошибками»/ (Contesina, 2013), «... Ему показалось, что у него в боку что-то лопнуло. Но через мгновение пришло осознание - это не его боль. [...] Истинные чувствуют друг друга...»/«Игра в себя», Книга фанфиков/ (Shifer dark, 2016); саме тіло здатне до реалізації цієї близькості: «Не совсем соображая, он сам подается вперед, чувствуя, как губы Джареда прижимаются к его шее...»/«Игра в себя», Книга фанфиков/ (Shifer dark, 2016); саме тіло стає вказівкою на травму/проблему, яку переживає/пережив персонаж («Не’s staring at Jared's throat. Can see the tendon go taut, give a quiver to show 
he's laughing, then relax again, over and over. He watches it almost hypnotically, trying to learn it...»/ /Like a detuned radio», Archive of Our Own/ (homo_pink, 2013)).

Часте акцентування на тілесному у фанфіках сприяє чуттєвості оповіді; водночас тілесність, тактильність, інтимність, яка завдяки цьому здобувається, сприяють розкриттю характеру персонажів, їхній само/ідентифікації. Власне, тіло стає «шляхом бути у світі» (переклад наш - 3. Г.) (Lushch, 2018).

\begin{tabular}{|c|c|}
\hline \multicolumn{2}{|r|}{ Фрейм «тіло» } \\
\hline $\begin{array}{l}\text { Руки (пальці) / } \\
\text { найчастіше } \\
\text { вживаний у } \\
\text { фреймі іменник/ }\end{array}$ & $\begin{array}{l}\text { Северус Снейп (зіллє вар) - саме так називають здебільшого цей } \\
\text { персонаж у текстах fan fiction, отже, через частину тіла здійснюється } \\
\text { ідентифікація персонажа), Джаред Падалекі (здебільшого } \\
\text { акцентувати зовнішність персонажа), Сандор Кліган (характер); у } \\
\text { слеші часто - сексуальний підтекст }\end{array}$ \\
\hline $\begin{array}{l}\text { Очі (погляд) } \\
\text { (найчастіше } \\
\text { вживаний у } \\
\text { фреймі іменник) }\end{array}$ & $\begin{array}{l}\text { Северус Снейп (характер), Джаред Падалекі (характер), Дженсен } \\
\text { Екклз (часто - акцент на зовнішність), Тиріон Ланістер (характер } \\
i \text { зовнішність). Щодо жіночих персонажів чи тих, які повинні } \\
\text { сприйматися як такі, то очі / погляд часто стають індикаторами } \\
\text { емочій / почуттів. }\end{array}$ \\
\hline Губи & $\begin{array}{l}\text { Дженсен Екклз (відверто сексуальний підтекст), Сандор Кліган } \\
\text { (зовнішність); у загальному вказівка на сексуальне бажання або } \\
\text { нервовість (кусати губи, стискати губи, облизувати губи тощо) }\end{array}$ \\
\hline Голос & $\begin{array}{l}\text { Северус Снейп, Дженсен Екклз, Сандор Кліган (характер, } \\
\text { сексуальний підтекст) }\end{array}$ \\
\hline $\begin{array}{l}\text { Ямо } \\
\text { щок }\end{array}$ & Джаред Падалекі (зовнішність і характер) \\
\hline Сідниці & $\begin{array}{l}\text { Дженсен Екклз, Джаред Падалекі, Санса Старк (зовнішність; у } \\
\text { слеші - сексуальний підтекст) }\end{array}$ \\
\hline Волосся & Санса Старк, Герміона Грейнджер, Луна Лавгуд (зовнішність) \\
\hline $\begin{array}{l}\text { Тіло в } \\
\text { загальному }\end{array}$ & $\begin{array}{l}\text { Санса Старк, Джон Сноу, Джаред Падалекі, Дженсен Екклз } \\
\text { (зовнішність) }\end{array}$ \\
\hline
\end{tabular}

Спектр значень, властивих тому чи тому феномену реальності, буде формувати в індивіда визначене бачення елементів реального світу (Бубнова, Казаченко, 2018). Звернімо увагу, що найчастіше фрейм «тіло» в жіночих персонажів реалізується як зовнішність, що загалом уписується в контекст масової літератури. Відповідно до результатів ВАЕ, саме зовнішність $є$ визначальним критерієм для усвідомлення образу жінки (концепт «руки жінки»): 100\% респондентів надають асоціації, які актуалізують саме ознаки 
зовнішності. Найчастотнішими асоціаціями «краса» (близько 2\%), «пальці / нігті» (більше 4\% реакцій).

Окремі акценти на очах / погляді дають вказівку на те, що жінка живе радше внутрішнім життям. Звідси і спосіб організації текстів, головним персонажем яких $\epsilon$ жінка, - оповідь часто ведеться від першої особи (наприклад, «Работа над ошибками», «Богарт Луны Лавгуд» (aliska145, 2015), «In the house of fallen angels» (rilla, 2006) та ін.). Результати ВАE засвідчують, що почуття, зокрема любові, $є$ важливим аспектом образу жінки в масовій свідомості (концепт «очі жінки»); таку реакцію надали 78 респондентів, із них 20 чоловічої статі. Важливо зазначити, що жінки, працюючи 3 літературним текстом, «схильні орієнтуватись [...] на свою чуттєву сферу» (Ващенко, Литвиненко, 2014), тож актуалізація текстом фанфіку, цільовою аудиторією якого є жіноча, образів, які стимулюють емоційно-почуттєвий потенціал реципієнта, $є$ цілком виграшною стратегією.

Чоловічі персонажі через фрейм «тіло» отримують не лише власне характеристики зовнішності, але й реалізують характер («Like a detuned radio», «Иди ко мне» (ivanova.alien, 2016), «In the house of fallen angels», «Работа над ошибками» тощо). Відповідно до гендерних стереотипних ролей, чоловіки повинні виконувати функцію зв'язку з зовнішнім світом, а забезпечення цієї функції в умовах, зокрема, масової літератури покладається саме на тіло. Як тіло виконує ці функції визначає чоловіка (наприклад, «Ты мужик, Падалеки. Ты в своей коляске такой самец, что многим на ногах бы у тебя поучиться»/«Иди ко мне», Книга фанфиков/ (ivanova. alien, 2016). Відтак, фанфік «In the house of fallen angels», подаючи образ Северуса Снейпа як божевільного, цілком виправдано поміщає його в кімнату в домі, про який ніхто не знає, й обмежує його спілкування виключно Герміоною Грейнджер - позбавлений свого гострого розуму, він не здатен використовувати своє тіло для адекватних своїм гендерному й соціальному статусам дій /Fan Fic Junkies/.

Важливо у цьому ключі звернути увагу на результати ВАE, оскільки відповідно до них, чоловік здебільшого реалізується саме через виконувану ним роботу (більше 90\% респондентів): асоціації «робота / праця / роботящий» (близько 2,5\% реакцій), а також пов'язані з ними «втома», «гроші / достаток» (близько $2 \%$ реакцій) 
творять смислове поле концепту «чоловічі руки»; асоціації «перемога / ціль / лідер / успіх / можливості / влада» тощо (близько 4\% реакцій респондентів) розкривають концепт «чоловічі очі». Відтак, побудова образу чоловіка в тексті fan fiction цілком узгоджується зі стереотипним уявленням про нього в масовій свідомості.

Персонажі багатьох текстів фанфіків отримують певні фізичні ушкодження чи мають хвороби, яких не мали персонажі оригінальних текстів. Так, Луна Лавгуд у фанфіці «Богарт Луни Лавгуд» виявляється жертвою згвалтування, як i, наприклад, Санса Старк, персонаж фанфіку «Адвокат» /Книга фанфиков/ (molinerova, 2016), що до всього не може мати дітей у зв’язку з численними побоями чоловіка Рамзі Болтона /Книга фанфиков/. Джаред Падалекі, перетворюючись на персонажа фанфіку «Иди ко мне», потрапляє в аварію і стає інвалідом / Книга фанфиков тощо.

Найчастіше певні фізичні травми, ушкодження чи хвороби стають екстраполяцією певних психологічних проблем персонажів текстів fan fiction. До прикладу, Северус Снейп із фанфіку «Работа над ошибками» після подій «поттеріани», вижив i потрапив до Азкабану. Не дивно, що в умовах, коли він змушений працювати на тих, хто його зневажає / боїться, у нього трясуться руки: «...эти руки дрожат. Мне становится страшно [...]. Сцепленные пальцы, чтобы унять мелкое противное дрожание. Он на грани. Толкнуть - и сойдет с ума. Я не видела такого даже в думосборе Дамблдора»/Книга фанфиков/ (Contesina, 2013). Дженсен Екклз, омега 3 незавершеного фанфіку «Игра в себя», змушений був зробити аборт у підпільному абортарії й мало не помер, тому його шрам на животі і поведінка, цілком не відповідна поведінці омеги, є адекватними ситуації, розробленій фанфіком / Книга фанфиков / (Shifer dark, 2016).

Можемо говорити і про акт ініціації персонажів fan fiction: зі стану персонажа (серійного) роману/фільму/серіалу вони переходять у стан персонажа фанфіка, отже, мають перенести певні психологічні i фізичні зміни, щоб максимально «адаптуватися» до вимог нового хронотопу. Варто зазначити, що така ініціація стає ключем до щастя, що забезпечує бажаний досвід тексту масової літератури (наприклад, «Ты, Дженс, дал мне новую жизнь, и я теперь уже не уверен, что, когда я мог ходить, было на сто процентов лучше» /«Иди ко мне», Книга фанфиков/ (ivanova.alien, 2016). 
Ініціація реалізується як хронотоп порогу і текстово - у рамках самого фанфіку; це апріорі передбачає певні зміни - і не лише хронотопічні, але й психологічні, емоційні, фізичні (тілесні) (наприклад, «После того, как Сэм вытаскивает Дина из Ада, тот перестает разговаривать. Совсем [...] они ездят в Импале, как ожившие манекены, и сидят в мотелях, как человеческие чучела прежде чем Сэм решает начать говорить за двоих»/ Hit the ground crawling», Книга фанфиков/ (IMPERIO 1, 2014) /виділення наше - 3. Г.; звернімо увагу, що втрата можливості говорити тримати контакт зі світом - стає наслідком саме реалізації хронотопу порогу і спричиняється до усвідомлення Семом Вінчестером своєї любові до брата: «Я пошел бы туда с переломанными ногами и простреленной головой, только чтобы снова увидеть тебя. Я пошел бы туда даже мертвым, если бы это потребовалось» /Hit the ground crawling, Книга фанфиков/ (IMPERIO 1, 2014), а також спричиняється до самоусвідомлення (наприклад, «It's him. He's the broken thing. It wasn't Jared. It was never Jared»/«Like a detuned radio», Archive of Our Own/ (homo_pink, 2013), що, знову ж таки, забезпечить happy end.

Варто звернути увагу: найчастіше персонажі чоловічої статі переживають підкреслено складні фізичні травми чи хвороби. Наприклад, Джаред Падалекі із «Нарисуй мне океан»/Книга фанфиков/ (SkukaSmertnaya, 2012) хворий на аутизм, а 3 «Like a detuned radio» втратив можливість говорити у зв'язку з нападом на нього у в'язниці; Дін Вінчестер із «Hit the ground crawling» отримує страшні травми в пеклі й не може говорити. На думку С. Антоніоллі, «зважаючи на кількість жанрів fan fiction, які працюють iз фізичним, психологічним та емоційним болем (наприклад, Hurt/ Comfort i Darkfic), видається, що безліч авторів фанів одержимі чоловічою вразливістю і болем. Причини цього феномену варто шукати у сприйнятті вразливості й болю у патріархаті. Історично, влада завжди налаштовувала молодих чоловіків сміливо й героїчно протистояти труднощам [...]. Цей механізм ретранслюється в масовій і високій культурі з винятковою регулярністю» (Antoniolli, 20162017) (переклад наш - 3. Г.). Коли ж із певних причин чоловік не може здолати слабкість, це може призвести до негативних наслідків як для нього самого (наприклад, низька самооцінка): «... Ты вовсе не глупый, вовсе не беспомощный. / - Я мешаю Дженсену [...]. 
Я глупый и мешаю ему»/хвороба//«Нарисуй мне океан», Книга фанфиков/ (SkukaSmertnaya, 2012), - так і для інших: «... у вас дрожат руки, сэр, - спокойно говорю я [...]. Он захлебывается на полуслове и умолкает, и я чувствую - может убить. Прямо сейчас. За то, что указала на его слабость» /розкриття психологічної травми через фізичний прояв/ /«Работа над ошибками», Книга фанфиков/ (Contesina, 2013).

Варто акцентувати увагу на тому, що найчастіше в аналізованих текстах така слабкість долається любов’ю («Работа над ощибками», «Богарт Луны Лавгуд», «In the house of fallen angels», «Нарисуй мне океан», «Иди ко мне»). Це засвідчує типовість цього мотиву для fan fiction. Ідеться також і про типовість його для масової літератури, зокрема для текстів жанру бульварного / любовного роману. Саме у зв'язку з цим актуалізується типовий для аналізованих текстів fan fiction happy end. Цікаво, що відповідно до результатів ВАЕ, важливою ознакою образу жінки $є$ iї соціальний статус, який реалізується через чоловіка: близько $3,4 \%$ реакцій (концепт «руки жінки») пов'язані з заміжжям (подружжя / весілля / наречена / заміжня / заміж / шлюб) та сім'єю (сім'я / мама / дитина) - близько 2\%. Реакції фрейму «сім'я» надавали виключно респонденти жіночої статі. Тексти fan fiction, які ми аналізували, здебільшого не подавали одруження як розв'язку сюжету, але тенденція розгортання тексту цілком може актуалізувати у свідомості саме такий happy end.

Наявність фізичної травми / хвороби, яка може бути екстраполяцією певної психологічної / емоційної травмованості індивіда, стає умовою happy end тексту fan fiction, що реалізується як любов (залишитися разом навіки / to stay together ever after). Водночас варто зазначити, що так у fan fiction може здійснюватися міф масової культури про красуню (красеня) і чудовисько. До прикладу, текст «Несбывшееся» (Лекочка, 2012) подає образ Сандора Клігана так: «Девушка видела только ту сторону его лица, что не была сожжена и удивленно ловила себя на мысли, что если бы Гора в детстве не изуродовал его, то Сандор был бы красив» / Книга фанфиков / (виділення наше - 3. Г.). Натомість текст фандомний «The Song of Ice and Fire» Дж. Мартіна надає інакші характеристики: «It (a helm - the author - Z. H.) was fashioned in the likeness of a snarling black hound, fearsome to behold, but Tyrion had always thought it a great improvement over Clegane's hideously burned 
face», «... his mouth twisted in a terrible mockery of a smile...» aбo "The left side of his face was a ruin. His ear had been burned away; there was nothing left but a hole. His eye was still good, but all around it was a twisted mass of scar, slick black flesh hard as leather, pocked with craters and fissured by deep cracks that gleamed red and wet when he moved» (Martin, 1996) (виділення наше - 3. Г.). Любов прекрасної Санси Старк до нього, Сандора Клігана, у фанфіках стає нагородою за перенесені страждання, зокрема й фізичні - зокрема й у фандомному тексті («Пташка была отчаянно восхитительна нежданное и запретное счастье...» (виділення наше - 3. Г.) / «Несбывшееся», Книга фанфиков / (Лекочка, 2012).

Варто також зазначити, що й фандомний текст подає образ Сандора Клігана як типовий для міфа про красуню і чудовисько, однак важко говорити про цілковиту його реалізацію в цьому тексті, найперше - у зв'язку з його (тексту) незавершеністю. «Strong hands grasped her by the shoulders, and for a moment Sansa thought it was her father, but when she turned, it was the burned face of Sandor Clegane looking down at her...» (Martin, 1996) (виділення наше - 3. Г.) - саме через фізичний контакт (руки - плечі) здійснюється психоемоційне сприйняття персонажа (батько - надійність, захист), причому саме у ключі масоволітературного його потрактування.

Персонажі жіночої статі (або омеги 3 омегаверсуму), переживають травми, пов'язані здебільшого зі згвалтуванням i/чи втратою функції дітонародження (наприклад, через згвалтування). «... Когда они (магические существа - автор - 3. Г.) двигались внутри меня, я чувствовала, как их когти впиваються в кожу. И я подавалась телом так, как им хотелось, только чтобы они не ранили меня еще глубже. / И вот уже несколько месяцев я продолжаю задавать себе вопрос: «Неужели мне настолько хотелось выжить?» /«Богарт Лунь Лавгуд», Книга фанфиков/ (aliska 145, 2015); «Его пальцы прикасаються к моей коже, словно пауки. Липкие и грязные [...] Я безсильна. Боль пронизывает тело, перед глазами плавают цветные пятна, корда Чарли для пущего послушания дергает меня за волосы [...] Это отвратительно» (виділення наші - 3. Г.) /«Работа над ошибками», Книга фанфиков/ (Contesina, 2013) - звернімо увагу, що два різні тексти подають акт згвалтування дуже подібно: тіло / шкіра (у фанфіках найчастіше стосується саме жіночих персонажів), позбавлення сили й захисту 
(що теж реалізується на фізичному / тілесному рівні), вторгнення когось/чогось чужого, ворожого, біль.

Фрейм «зовнішні фізичні ушкодження»

Шрами (в чоловіків залишаються (Дін Вінчестер, «Hit the ground crawling»), в жінок - сходять (Санса Старк, «Адвокат»); виняток - Дженсен Екклз, «Игра в себя»

Сиве волосся (Гаррі Поттер, «Работа над ошибками»)

Відсутність пальців на одній руці (Гаррі Поттер, «Работа над ошибками»; Дін Вінчестер, «Hit the ground crawling»)

Сексуальне i/чи психологічне насилля (Санса Старк, «Адвокат»; Дженсен Екклз, «Игра в себя»; Герміона Грейнджер, «Работа над ошибками»; Луна Лавгуд, «Богарт Луны Лавгуд»)

\section{Фрейм «хвороби»}

Аутизм (Джаред Падалекі, «Нарисуй мне океан»)

Інвалід унаслідок аварії (Джаред Падалекі «Иди ко мне»)

$\mathrm{He}$ може говорити (Джаред Падалекі, «Like a detuned radio»; Дін Вінчестер, «Hit the ground crawling»)

$\mathrm{He}$ може мати дітей унаслідок насилля, зокрема на сексуальному підгрунті (Санса Старк, «Адвокат»; Дженсен Екклз, «Игра в себя»)

Персонажі текстів фандомів, які мали певні зовнішні ушкодження (Сандор Кліган, Тиріон Ланістер, Гаррі Поттер, Северус Снейп), у хронотопі, пропонованому фанфіком, нових шрамів/травм/хвороб практично не отримують. Їхні фізичні ушкодження $\epsilon$ своєрідним унаочненням пережитого досвіду й «виправдовують» мінімальні зміни їхньої зовнішності у fan fiction та happy end, який вони заслужили своїми діями і стражданнями в тексті-оригіналі та фанфіці. Так, Гаррі Поттер і Северус Снейп y fan fiction здебільшого переживають психологічні/психічні травми (Гаррі Поттер із фанфіків «Работа над ошибками» та «Луна Лавгуд и ее коллекция мозгошмыгов» (Avada_36, 2016) або Северус Снейп iз «Работа над ошибками» чи «In the house of fallen angels»): Гаррі Поттер - обраний, шрам на його чолі - то мітка смерті; Северус Снейп Дж.К. Ролінг помер від укусу змії Волдеморта Наджіні; очевидно, якщо він вижив у тексті fan fiction, у нього має бути шрам на шиї.

Звернімо увагу, що деякі фанфіки подають ці образи помітно «покращеними», принаймні візуально. Северус Снейп у тексті «Работа над ошибками» постає таким: «У него красивые руки. Тонкие пальцы, пара мелких шрамов...», «...бархатным голосом [...] продолжает», «Он... обыкновенный [...]. Терпкий запах кожи - еле уловимый, чуть холодный» (Contesina, 2013) (виділення 
наше - 3. Г.). Водночас фандомний текст подає інший образ: «His eyes were black like Hagrid's, but they had none of Hagrid's warmth. They were cold and empty and made you think of dark tunnels» (Rowling, 1997) (виділення наше - 3. Г.). Якщо зважити на інші характеристики зовнішності Северуса Снейпа Дж.К. Ролінг (масне волосся, жовті зуби, гачкуватий ніс тощо), то створений образ візуально відштовхує, а образ фанфіків створений для того, щоб приваблювати.

Важко знайти фанфік серед аналізованих, у якому жіночий персонаж має певні зовнішні фізичні вади (які не зникнуть із часом принаймні). Але позбавлення жінки функції дітонародження або перенесення згвалтування, яке може серед небажаних наслідків мати і страх доторків, отже, унеможливлення сексуальних стосунків iз чоловіком, отже, позбавлення функції дітонародження («Я с ужасом смотрю, как он тенет руку через стол ко мне. Это хуже, чем сто проклятий - то, что он сейчас ко мне прикоснется» /«Работа над ошибками», Книга фанфиков/ (Contesina, 2013), по суті, пошкоджує природу жінки, так само як хвороби / аварії / прокляття, пошкоджуючи тіло чоловіка, позбавляють його можливості виконання функції зв'язків із зовнішнім світом. Емоція завжди характеризується валентністю: позитивна чи негативна (Peer, Chesnokova, 2018); переживання цілого спектру емоцій щодо персонажів значно збільшує рецептивний потенціал тексту фанфіку.

\section{Висновки}

Fan fiction $є$ одним зі зразків масової віртуальної літератури. Дискурс тілесності, реалізований у текстах fan fiction, стає для неї структуротворчим; по-перше, він емоційно наближує текст фанфіку до читача, по-друге, забезпечує здійснення бажаного досвіду сексуальних / любовних взаємостосунків з Іншим, по-третє, актуалізує базові потреби індивіда (через секс реалізуються безпека й любов). Фрейм «тіло» актуалізує гендерні стереотипи масової літератури й загалом культури: жінка сприймається через зовнішність як така, що акумулює в собі емоції / почуття; чоловік постає як характер, який забезпечує зв'язок із зовнішнім світом. Результати ВАЕ засвідчують, що, окрім реалізації й закріплення певних гендерних стереотипів, цей фрейм «вмикає» цілком 
позитивні асоціації масової свідомості, які актуалізуються ґендером та досвідом (уже-знане = безпека, комфорт).

Важливо зазначити, що результати проведеного дослідження можуть мати прикладний характер: сьогодні відбувається чимало конкурсів літературних текстів, зокрема й засобами мережі Інтернет (наприклад, «Сучасна попелюшка» тощо), а використання стратегій, описаних у статті (як-от реалізація дискурсу тілесності, стереотипні гендерні ролі, традиційний happy end тощо), дозволить знайти свою аудиторію й авторові-початківцю.

Перспективи подальших досліджень вбачаємо в компаративному аналізі образів текстів фандомів та fan fiction, явища Out of Character як психологічного й герменевтичного феномену, специфіки текстів фанфіків із позначкою «Смерть основного персонажа» саме в контексті дослідження дискурсу тілесності.

\section{Література}

Балабан О. Поняття ментального лексикону та моделі організації знань у пам'яті людини. Psycholinguistics. Психолінгвістика. Психолингвистика. 2017. № 21(2). C. 12-26.

Бубнова И., Казаченко О. Динамика смыслового содержания значения слова свобода. Психолінгвістика. Психолингвистика. Psycholinguistics. 2018. № 23(2). C. 11-25. doi.org/10.5281/zenodo.1199099

Ващенко I., Литвиненко О. Фактори ефективності сприймання літературних текстів. Східноєвропейський журнал психолінгвістики. 2014. № 1. С. 209-216.

Гадамер Г.Г. Герменевтика і поетика. Київ: «Юніверс», 2001. 288 с.

Засєкін С. Психолінгвістичні універсалії перекладу художнього тексту : монографія. Луцьк, 2012. 272 с.

Книга фанфиков. URL: ficbook.net/fanfiction.

Яус Г.Р. Досвід естетичного сприйняття і літературна герменевтика / пер. 3 нім. Р. Свято і П. Таращука. Київ: Видавництво Соломії Павличко «Основи», 2011. 624 c.

Antoniolli, C. (2016-2017). Questions of Sexual Identity and Female Empowerment in Fan Fiction. Venice: Ca' Foscari University of Italy. URL: https://www.academia. edu/Documents/in/Fanfiction Studies

Archive of Our Own. URL: http://archiveofourown.org

De Deyne, S., \& Storms, G. (2008). Word associations: Network and semantic properties. Behavior Research Methods, 40(1), 213-231. doi: 10.3758/ BRM.40.1.213

Estes, Z., Golonka, S., \& Jones, L.L. (2011). Thematic thinking. The apprehension and consequences of thematic relations. Psychology of Learning and Motivation, 54, 249-294. doi.org/10.1016/B978-0-12-385527-5.00008-5

Fan Fic Junkies : When a couple captures our hearts. URL: www.fanfiction-junkies.de Lushch, U.I. (2018). The Self in the World : Overcoming Dualism and Shaping New Landmarks. Антропологічні виміри філософських досліджень. Вип. 13. C. 17-29. DOI: 10.15802/ampr.v0i13.122840 
Martin, G.R.R. A Game of Thrones (Song of Ice and Fire). URL: http://www.bestnovels.com/George R.R. Martin/A Game of Thrones/17.html

Ober, B.A., \& Shenaut, G.K. . (2006). Semantic Memory. In M.J. Traxler and M.A. Gernsbacher (Eds.). Handbook of Psycholinguistics, (pp. 403-455). New York: Academic Press.

Peer, W., \& Chesnokova, A. (2018). Reading and Rereading : Insights into Literary Evaluation. Advanced Education, 9, 39-46. doi: 10.20535/2410-8286.125730

Pryhodko, V.V., \& Rudenko, S.V. (2018). Body and Space Relationship in the Research Field of Phenomenological Anthropology : Blumenberg's Criticism of Edmund Husserl's «Anthropology Phobia». Антропологічні виміри філософських досліджень. Вип. 13. С. 30-40. doi: 10.15802/ampr.v0i13.125512

Psycholinguistics. A Survey of Theory and Research Problems. (1954). Ch.E. Osgood, T.A. Subeok (eds.). Baltimore: Waverly Press, Inc.

Rowling, J.K. Harry Potter and the Sorcerer's Stone. URL: www2.sdfi.edu.cn/netclass

Vivas, L., Manoiloff, L., García, A.M., Lizarralde, F., \& Vivas J. (2018). Core Semantic Links or Lexical Associations: Assessing the Nature of Responses in Word Association Tasks. Journal of Psycholinguistic Research. Sept. URL : https://www.springer.com/psychology/journal/10936. doi: 10.1007/s10936-0189601-8

\section{References}

Balaban, O. (2017). Poniattia mentalnoho lexykonu ta modeli orhanizatsii znan u pamjati ludyny [The Notion of Mental Lexicon and the Models of Knowledge Organization in Person's memory]. Psycholingvistyka - Psycholinguistics, 21(2), 12-26 [in Ukrainian].

Bubnova, I., \& Kazachenko, O. (2018). Dinamika smyslovogo soderzhania slova svoboda [Dynamics of the Semantic Content of the Word Freedom]. Psycholingvistyka - Psycholinguistics, 23(2), 11-25 [in Russian]. doi.org/10.5281/ zenodo.1199099

Vashchenko, I., \& Lytvynenko, O. (2014). Faktory efektyvnosti spryimanna literaturnyh tekstiv [Factors Affectings the Effectiveness of Literary Text Perception]. East European Journal of Psycholinguistics, 1, 209-216 [in Ukrainian].

Gadamer, H.G. (2001). Hermenevtyka i poetyka [Hermeneutics and Poetics]. Kyiv: Univers [in Ukrainian].

Zasiekin, S. (2012). Psyholingvistychni universalii perekladu hudozhnoho tekstu [Psycholinguistic universals of the artistic text translation]. Luts'k: Volyns'kiy Natsional'niy universytet imeni Lesi Ukrainky [in Ukrainian].

Kniga fanfikov (2018). [The Book of Fanfics] [in Russion].

Yaus, H.R. (2011). Dosvid estetychnoho spryiniattia i literaturna hermenevtyka [The experience of aesthetic perception and literary hermeneutics]. Kyiv: Osnovy [in Ukrainian].

Antoniolli, C. (2016-2017). Questions of Sexual Identity and Female Empowerment in Fan Fiction. Venice: Ca' Foscari University of Italy. URL: https://www.academia. edu/Documents/in/Fanfiction_Studies

Archive of Our Own. URL: http://archiveofourown.org

De Deyne, S., \& Storms, G. (2008). Word associations: Network and semantic properties. Behavior Research Methods, 40(1), 213-231. doi: 10.3758/ BRM.40.1.213 
Estes, Z., Golonka, S., \& Jones, L.L. (2011). Thematic thinking. The apprehension and consequences of thematic relations. Psychology of Learning and Motivation, 54, 249-294. doi.org/10.1016/B978-0-12-385527-5.00008-5

Fan Fic Junkies : When a couple captures our hearts. URL: www.fanfiction-junkies.de

Lushch, U.I. (2018). The Self in the World : Overcoming Dualism and Shaping New Landmarks. Antropologichni vymiry filosofs'kych doslidzhen - Antropological Measurements of Philosophical Research, 13, 17-29 [in English]. DOI: 10.15802/ ampr.v0i13.122840

Martin, G.R.R. A Game of Thrones (Song of Ice and Fire). URL: http://www.bestnovels.com/George R.R. Martin/A Game of Thrones/17.html

Ober, B.A., \& Shenaut, G.K. (2006). Semantic Memory. In M.J. Traxler and M.A. Gernsbacher (Eds.). Handbook of Psycholinguistics, (pp. 403-455). New York: Academic Press.

Peer, W., \& Chesnokova, A. (2018). Reading and Rereading : Insights into Literary Evaluation. Advanced Education, 9, 39-46. doi: 10.20535/2410-8286.125730

Pryhodko, V.V., \& Rudenko, S.V. (2018). Body and Space Relationship in the Research Field of Phenomenological Anthropology : Blumenberg's Criticism of Edmund Husserl's «Anthropology Phobia». Antropologichni vymiry filosofs 'kych doslidzhen - Antropological Measurements of Philosophical Research, 13, 30-40 [in English]. doi: 10.15802/ampr.v0i13.125512

Psycholinguistics. A Survey of Theory and Research Problems. (1954). Ch.E. Osgood, T.A. Subeok (eds.). Baltimore: Waverly Press, Inc.

Rowling, J.K. Harry Potter and the Sorcerer's Stone. URL: www2.sdfi.edu.cn/netclass Vivas, L., Manoiloff, L., García, A.M., Lizarralde, F., \& Vivas J. (2018). Core Semantic Links or Lexical Associations: Assessing the Nature of Responses in Word Association Tasks. Journal of Psycholinguistic Research. Sept. URL : https://www.springer.com/psychology/journal/10936. doi: 10.1007/s10936-0189601-8

\section{АНОТАЦІЯ}

У статті досліджується дискурс тілесності, типові персонажі, стереотипні гендерні ролі текстів fan fiction, грунтованих на «поттеріані» (серія книг Дж.К. Ролінг; серійний фрільм), «Надприродному» (серіал), «Пісні льоду й полум'я» (серія книг Дж. Мартіна) / «Грі престолів» (серіал). Авторка використовує психолінгвістику (фреймовий аналіз та вільний асоціативний експеримент), герменевтику, елементи компаративного аналізу для опису основних характеристик персонажів та пояснення особливостей їхньої тілесної / фізичної взаємодії.

Fan fiction $\epsilon$ різновидом віртуальної масової літератури, відтак вона має особливі риси, властиві масовій літературі загалом, наприклад, "комфортне» читання, типові персонажі в типовому драматичному сюжеті, часто - happy end $i$ m.d.

Дискурс тілесності є одним із найважливіших аспектів текстів fan fiction, тому що досвід сексуальних взаємодій є бажаним для людини; че основа життя (дивитись піраміду базових потреб індивіда А. Маслоу). 
Фрейм "тіло» охоплює не тільки власне секс (як фрізичний/фрізіологічний контакт між індивідами), але й любов і безпеку. Найчастотнішими елементами аналізованого фррейму $\epsilon$ «руки / пальці» й "очі / погляд». Важливо відзначити, що руки й очі чоловіка часто показують його характер. Але очі й руки жінки реалізують ії емоції й почуття. Це залежить від стереотипних гендерних ролей масової культури: чоловік повинен виконувати функцію взаємодії з зовнішнім світом, а жінка, своєю чергою, - функцію забезпечення безпечного життя всередині (дітонародження), що й підтверджує вільний асоціативний експеримент, проведений нами.

Фізичні ушкодження (шрами, травми, хвороби - для чоловіка, зґвалтування - для жінки) роблять персонаж більш емоційно близьким до читача текстів fan fiction, a також акцентують акт ініціації (перехід від тексту оригінального (фандому) до тексту fan fiction).

Ключові слова: fan fiction, оригінальний текст, франдомний персонаж, персонаж франфіку, дискурс тілесності, фрізичні та психологічні ушкодження.

\section{Годунок Зоряна. Дискурс телесности в текстах Fan Fiction}

\section{АННОТАЦИЯ}

В статье исследуется дискурс телесности, типичные персонажи, стереотипные гендерные роли текстов франфиков, основанных на «Гарри Поттере» (серия книг Дж.К. Роулинг; серийный фильм), "Сверхъестественном" (сериал), «Песне льда и огня" (серия книг Дж. Мартина) / «Игре престола» (сериал). Автор использует психолингвистику (фреймовый метод и свободный ассоциативный эксперимент), герменевтику, некоторые элементы компаративного анализа, чтобы описать основные характеристики персонажей и объяснить особенности их сексуальных и любовных взаимоотношений.

Fan fiction - это вид виртуальной массовой литературы, поэтому она имеет особые черты, присущие массовой литературе вообще, например, «удобное» чтение, типичные персонажи в типичном драматическом сюжете, часто - счастливый конец и т.д.

Дискурс телесности является одной из самых важных частей текстов франфиков, потому что опыт сексуальных/любовных взаимоотношений желателен для человека и является основой его жизни (смотреть, например, пирамиду потребностей индивида А. Маслоу). Фрейм "тело», структурирующий анализируемый дискурс, охватывает не только секс, но и любовь и безопасность, которые стают возможными именно через физический контакт. Наиболее частотными существительными фрейма «тело» являются "руки / 
пальцы» и «глаза/взгляд». Важно отметить, что руки и глаза мужчины часто показывают его характер, а глаза и руки женщины - ее эмоции и чувства. Это зависит от стереотипных гендерных ролей массовой культуры: мужчина должен исполнять функцию взаимодействия с окружающим миром, а у женщины есть функция обеспечения безопасной жизни внутри себя (деторождение), что и подтверждает свободный ассоциативный эксперимент, проведенный нами.

Физические повреждения (шрамы, травмы, болезни - для мужчины, изнасилования - для женщины) делают персонажей более эмоционально близкими к читателю франфиков; кроме того, они акцентируют акт инициации (перехода от франдомного текста к тексту fan fiction).

Ключевые слова: фанфик, исходный/фандомний текст, персонаж, персонаж франфика, дискурс телесности, фризический и психологический ущерб. 